0.7231

第六表の平均 $\mathrm{Cu}$ 含付量より繊維素 $\mathrm{C}_{6} \mathrm{H}_{10} \mathrm{O}_{5}$ に對する其結合モル數を計算しナトリウム監の ナトリウム絬合モル數と此較せば

$\begin{array}{ccc}\text { 斌 料 } & \text { 銅絬合モル數 } & \text { ナトリゥム結合モル數 } \\ 1 & 0.36 & 0.67 \\ 2 & 0.43 & 0.80\end{array}$

銅は二價として結合モル數はナトリウム監のナトリウム結合モル數より幾分大なり其理由は第 一銅の存在汇任るにあらさるか大體に於て當量なるは疑ひの䟻地なし

本研究は帝國學士院の研究費補助により行ひたるものなり又研究上工學士岡田展三氏の助力に 負ふ所多し其厚意汇劃し感謝の意を表す

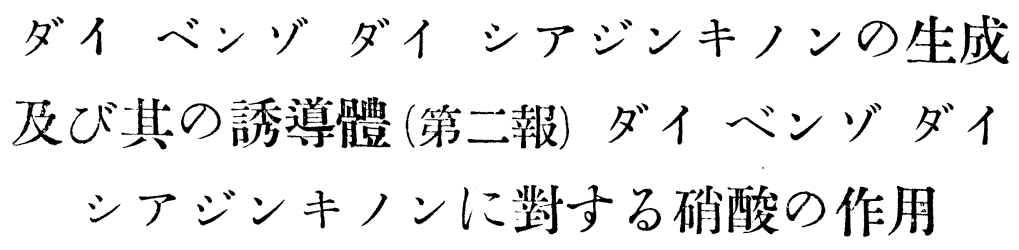

（來北帝國大學工學部化學工學孯賽駿室）（昭和二年九月一三日受理）

工學士柴田林之助

ダイベンゾ ダイ シアシシンキノン〔I]（柴田、本誌、第三○編、438頁)を硝酸によりて處理 すれ法オレーンジ II の如き外觀を付する粉末状物質を得、此のものは多くの有機溶劑に溶解せ すと踓も稀薄なるアルカリにた易く解け酸によりて再で沈澱す又そのソヂウム、ポタッシウム及 びつムモニウム化合物は何れも結晶として取り出す事を得例へば此の橙色の粉末狀物質を稀薄な る苛性曹達溶液の適量と數分間靜かに加熱すればソヂウム化合物を生成す赤褐色板狀結晶なりボ タツシウム化合物は針狀、アムモニウム化合物は板狀に結晶す此等は水に可溶性にしてアルコー ル其の他の有機溶劑に不溶性なり

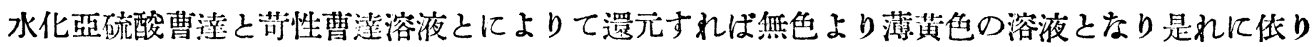
種々の纎維を青き色相に染める事は原の色素 ダイ ベンゾダイ シアシシンキノンに依ると全く同 样なり

分析の結果に低ればダイ ベンゾダイ シアシシンキンが硝酸に依りて受くる作用はナイトレ ーションには非ずして酸化なり即ちサイオエーテルからスルフォキサイドを生ずると同樣に二つ のシアジン環の中の硫黄原子が酸素原子と結合して相當するスルフォキサイド[II]を生ずるな り而して此の結果活性となれる二つのイミノ基の水素原子は金屬原子に依りて置換せられ得る性 


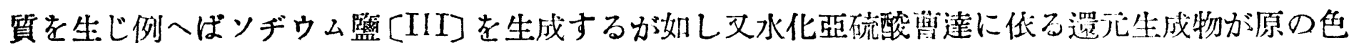
素ダイベンソダイシアジンキノン〔I]に外ならざる可き事は一般にス几フォキサイドはた易 く還元せられサイオェーテルを生和る通有性它有する事より推理し得可し分析の結果子亦一致す
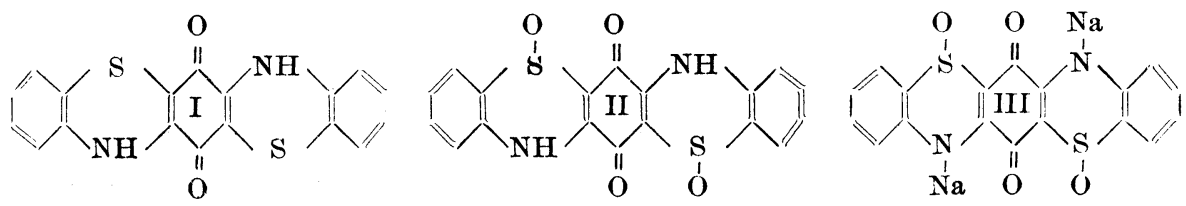

此の反應の經過はダイベンゾダイシアジンキノンの分子內の硫黃原子の位罳を明かに說明する ものにして即ち構造式〔I]を確實に支持するものなり(本誌、第二八絧、892 项及び第三○緑、438 頁參照)

ヌダイベンソダイシアジンキノンは其の生成にあたり 結晶する以外再結晶する事能はざり しが此處に其のスルフォキサイドの監として永に可溶性なる結晶性物質となす事を得たるは有利 なる結果なり $2: 5$ ダイ イミノフェニールキフン（1.4）の硫黃熔融によりてダイベンゾダイ シアジンキノンを合成する時是れが分離法として著者はさきに濃硫酸による抽㥘を用てたるが

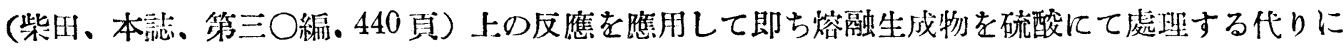
硝酸にて處理しスルフォキサイドとなし是れを䱘薄なるアムモニア水にて抽归する事に依り同じ 目的を達し得る事を確めたり

\section{實驗部 スルフオキサイドの製造}

發烟硝酸（其の比重 1.45) $12 \mathrm{~g}$ と水醋酸 $12 \mathrm{~g}$ とを小さきビーカーにとり是れを水の上に冷却 し置き $5.2 \mathrm{~g}$ のダイ ベンゾダイシアシンンフンを少量宛加へよく摩擦し个ら瀷找すれ深青 色の色素は赤登色几變はり粘稠なる糊狀となる是れを冷水の中に注ぎ生じたる沈澱を水にて良く 洗ひ乾燥すれば橙色の粉末なり

此の物は多くの溶劑に不溶解疗れども稀薄なるアルカリに溶解し血赤色溶液を生ず故に稀溥な るアムモニ・ア水溶液となし 監酸にて中和して 沈澱せしめ精製する事を得收量 $5.4 \mathrm{~g}$ 、理諭數の $94.2 \%$ なり

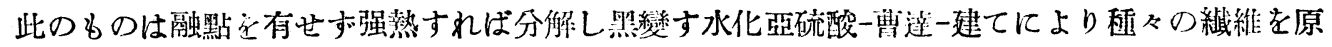
の色素之同一色相に䧱色す

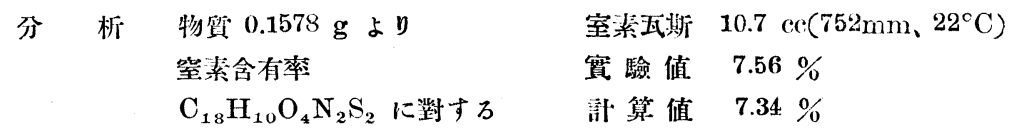
スルフオキサイドの還元＼cjkstart染色汒

$2 \mathrm{~g}$ のスルフォキサイドを $6 \mathrm{~g}$ の水化亞硫酸曹達と混合し $30 \mathrm{cc}$ の水にて糊狀となし溫もれば沈 
澱物の色は灰黃色となる是れに $30 \mathrm{ce} の 2 N$ 乴性曹達溶液を加へたる後溫湯を加人全體を $150 \mathrm{cc}$ となせば液に赤膯色を帶び是れを靜かに者沸する時は其色は漸次減退す更に $300 \mathrm{cc}$ の溫湯と $2 N$ の蒴性曹澾溶液 20cc とを扣ふれば僅かに赤く着色せる透明なる溶液を得是れを硝子フィルター にて滤過し滤液に空啭をふきてみて振蕰すれば酸化行はれ深青色の色素を沈澱す是れダイベン ゾダイシアシシンキンに外ならず此の沈澱物を蒐め水洗したる後一規定の稀邷酸と溫め洗滌し 最後に水にて洗滌乾燥す 收量 $1.7 \mathrm{~g}$ 理論數の $95.5 \%$ なり

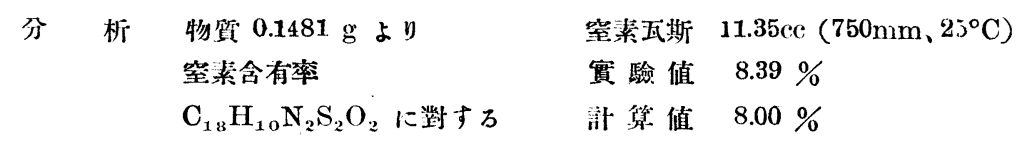

此の還元に於いて最初にスルフォキサイドは先づ夫れに相當するリューコ化合物を生ず可きも 反應は直ちに䢰みてダイ ベンゾダイ シアシンキノンのリューコ化合物となり斯くて此の還元生 成物を空乘に唒す㭙は酸化の結果ダイベンゾダイ シアジンキノンを生成するに到るものと䚋 察せるる從つてスルフォキサイドを用ひて染色せば繊維の上には結局原の色素が顯出するものな り、實際此の染浴を作るに際して氷化亞硫酸曹蓬及び悲性曹達溶液を加へたる後加熱を充分にし てスルフォキッイドの䢱元を充分ならしめざる可から秋然らざればスルフォキサイトの顯はる」 焉め染色は不純となるべし此の注意をなせばスルフォキサイドに變へたる後に染色をなす時に原 の色素を其睢用ふる時よりも遥かに純粹なる色相を得

\section{スルフオキサイドのソヂウム鹽老製造する方法}

$2.5 \mathrm{~g}$ のスルフォキサイドを $2 N$ の北性曹達溶液 $50 \mathrm{cc}$ に䀣濁して靜かに加熱沸䲲せしむればス

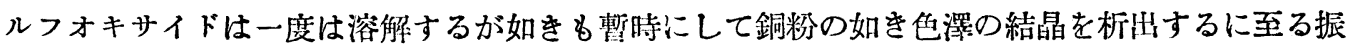
盜しながら煮沸するてと數分の後冷却し 50cc のアルコールを加へ放置し析出する結晶を分離し アルコールにて溜滌し乾燥す（收量 $1.5 \mathrm{~g}$ 理論数つ $54.3 \%$ ) 此のものは有機溶劑には不溶性なれ

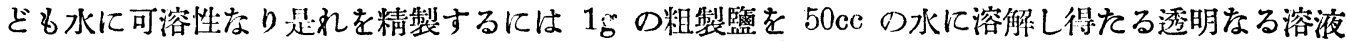


狀の結晶なり $0.6 \mathrm{~g}$ を得

此の監の水溶液に水化亞硫酸垂達を加へ還元を行ひ染色し得る事スルフォキサイドに於けると 同㥞なり此の染浴の中にてソヂウム原子はシァジンのリューコ化合物が生成すると同時にイミノ基 より㒕去するものと考へらる

分析 (1) 䇪 装 物貿 $0.1493 \mathrm{~g}$ より 窒菜含有寗 $\mathrm{C}_{18} \mathrm{H}_{8} \mathrm{O}_{4} \mathrm{~N}_{2} \mathrm{~S}_{2} \mathrm{Na}_{2}$ に對する

（2）ソヂウム物質 $0.1576 \mathrm{~g}$ より ソヂウム含有率 $\mathrm{C}_{18} \mathrm{H}_{8} \mathrm{O}_{4} \mathrm{~N}_{2} \mathrm{~S}_{2} \mathrm{Na}_{2}$ に對する
等装瓦洀 $9.05 \mathrm{cc}\left(752 \mathrm{~mm}, 24.5^{\circ} \mathrm{C}\right)$

惯 驗 值 $6.67 \%$ 計算值 $6.57 \%$ 犊酸ナトリウム $0.0482 \mathrm{~g}$ 右得:

實 驗 值 $9.90 \%$ 訣算值 $10.79 \%$ 